\title{
The Effectiveness of Inclusive Education and Child Protection Training on Understanding Inclusive Education Subject Matter
}

\author{
Munawir Yusuf, Salim Choiri, Gunarhadi \\ Special Education Department, Faculty of Teacher Training and Education, Universitas Sebelas Maret, Indonesia \\ Email: munawir_uns@yahoo.co.id
}

\begin{abstract}
The main objective of this study is to examine the effectiveness of inclusive education trainning for the teacher using of the main learning material (BPU) of Inculsive Education and The Child Protection as compulsory course in Faculty of Teacher Training and Education, Sebelas Maret University. The quantitative research method was adopted for this study using twenty five valid item in pre-post questionnaires completed by twenty five teacher in Faculty of Teacher Trainning and Education, Sebelas Maret University. The data were collected using instrument that measures the concept of inclusive education and child protection as pre-post questionnaires. The data collected were analyzed using quantitative analysis through Paired sample t-test to find the difference in distance run between pre and post test. Based on the results, there was difference between mean score of pretest and posttest $(17,32-19,84)$. The paired sample t-test was used to determine whether there was a statistically significant difference in distance run between the two trials. The paired sampel t-test showed that $\mathrm{p}$-value is lower than $\alpha$-value $(0,000<0,05)$. The findings indicates that trainning for teacher using the main learning material (BPU) of Inculsive Education and The Child Protection is effective to enhance the comprehension in understanding inclusive education course as compulsory course in Faculty of Teacher Training and Education, Sebelas Maret University
\end{abstract}

Keywords: trainning, inclusive education, handbook

The issue of inclusive education and child protection has become an important theme in the education field in Indonesia. Not only because the two issues are part of the 'international issues' that are always inflated by the developed countries so that the developing countries participate in ratifying various world conventions in order to realize the right to education for all children, but it is also increasingly recognized that building a broad and quality education, is not possible to be discriminatory only prioritize those who are 'normal' and / or who have the potential above the average or extraordinary. Children with conditions of physical, mental, emotional and / or social and economic limitations, including disability groups, must be an integral part of the future education system. Inclusive education is one form of non-discriminatory education service system that will be enforced in all regular schools in elementary, junior and senior high schools (Yusuf et al., 2017).

Inclusive education is an open and learningfriendly education by promoting respect and embracing differences. For that reason, inclusive education is understood as an approach that seeks to transform the educational system by removing barriers that can prevent individual students from participating fully in education equipped with support services. "Inclusive" is a simple and practical change that allows every individual with every difference to be successful in learning. This change benefits not only the oftenmarginalized individual as a child with special needs, but also all children and parents, all teachers and school administrators, and every member of the community and neighborhood.

Inclusive education has diverse understanding. Stainback and Stainback (1990) argue that inclusion schools are schools that accommodate all students in the same class. The school provides a decent, challenging education program, but matches the abilities and needs of each student, as well as the help and support that teachers can make for children to succeed. Moreover, inclusive schools are also where every child can be accepted, become part of the class, and help each other with teachers and peers, as well as other members of the community so that individual needs can be met.

Furthermore, Staub and Peck (1995) suggest that inclusion education is the placement of children with moderate, mild, and severe degree disorders in full in regular classes. This suggests that the regular class is a relevant place of learning for children with disabilities, regardless of the type of disorder and gradation. Meanwhile, Sapon-Shevin (O’Neil, 1995) states that inclusion education as an educational service system requires that all children with disabilities be served in nearby schools, in regular classes with their 
peers. Therefore, it emphasizes the restructuring of schools, so that it becomes a community that supports the fulfillment of the special needs of each child, meaning rich in learning resources and get support from all parties, ie students, teachers, parents, and the surrounding community. Through inclusive education, children with special needs together with other children (normal) are educated to optimize their potential. This is based on the fact that in society there are normal children and children with disabilities (disabled) that can not be separated as a community.

In countries that have long implemented inclusive education programs, especially in developed countries, inclusive education is more broadly understood in the context of a school culture that emphasizes how schools, classes, and curriculum structures are designed for all children to follow learning and develop optimally (Kugelmass, 2004). Other evidence of inclusion education in developed countries is written by Schwab (2014), which means inclusive education is not just placing children with or without special needs in a similar class, (such a practice represents a form of integration in Germany) but the meaning inclusion is the social participation of all students. In the context of inclusive education development, it is necessary to survey not only the academic outcomes but also the social outcomes. In a broader context, inclusive education can be interpreted as a form of educational reform that emphasizes anti-discrimination, the struggle for rights, justice and the expansion of educational access for all, improving the quality of education, strategic efforts in completing 9-year compulsory education and changing attitudes community against special children (Sunaryo, 2009).

Inclusive education is a strategy to promote effective universal education because it can create schools that are responsive to the actual needs of children and society. Thus, inclusive education ensures access and quality of education. Inclusive education has grown rapidly in developed countries, while in Indonesia inclusive education is a new paradigm as it has only been developed since 2003 (Yusuf et al., 2012). As a new paradigm, then in its implementation still need various supporting tools, socialization and educational process to all stakeholders.

On the other hand, the issue of child protection has also surfaced in the last decade. Since the enactment of UU No. 23/2002 on Child Protection, cases of violence against children are increasingly revealed to the surface, and the interesting cases of violence against children are not only committed by uneducated people, even in educational institutions or schools. Data released by the Indonesian Child Protection Commission (KPAI) of 2014, presented by the Data and Information section shows that over the past 4 years (2011 - 2014), the number of reported cases of child abuse continues to increase to 669 cases (physical violence), 244 cases (psychological violence), 2,296 cases (sexual violence), 610 cases (trafficking and exploitation). According to Sunardi (2009), based on child protection clusters, in addition to cases of violence as described above, cases of violence against children that occurred in the educational environment in the last 4 years has reached a fantastic number of 1,480 cases. This shows that the school environment has not become a safe place for children to live freely, comfortably, safely and protected. Based on these data indicate that in Indonesia, the child has not been a well-protected individual in his life, both in the family environment, society even in the educational environment. This fact also suggests that the understanding of actors and educational activists on child protection is still far from expectations and hence the need to create a system that allows teachers and prospective teachers to have the insights, attitudes and skills necessary to create an environment of child-friendly education, spared from attitudes and behaviors that can be categorized as forms of violence against children.

To avoid the rights of children to be fulfilled and all children get the protection and good treatment in order to foster full participation for every individual child in school, then in addition to teachers and principals should be given systematic and systemic socialization, not least for the candidate teachers in this case students at the College of Education get an understanding of inclusive education and child protection through relevant lectures. Several study programs in the College of Education have set the course of inclusive education as compulsory subject. Therefore the course content needs to be expanded not only on inclusive education but also on child protection. Through this research is expected to assist each university in order to develop and enrich the competence of prospective teachers with content of inclusive education and child protection.

The theme of inclusive education needs to be extended again with the issue of child protection due to the fact that the understanding of education actors in schools on child protection and child welfare issues is still very low. Many things are thought by the teacher that a behavior is still considered reasonable, but according to the existing legislation system has entered the legal realm that can ensnare the teacher because it is considered to have violence against children. It is therefore urgent that inclusive education materials and child protection be included in the curriculum of higher education in all existing Study Programs in the College of Education. Through the course of Inclusive Education is expected to equip prospective teachers in creating a school that is friendly to all children without discrimination. This research is one form of social responsibility of Sebelas Maret University in order to create an inclusive and non-discriminatory society. 
Table 1. Statistic descriptive of pretest score

\begin{tabular}{lllllll}
\hline & N & Minimum & Maximum & Mean & Std. Deviation & Variance \\
\hline PRETEST & 25 & 13 & 22 & 17,32 & 2,076 & 4,310 \\
Valid N & 25 & & & & & \\
\hline
\end{tabular}

Table 2. Statistic descriptive of posttest score

\begin{tabular}{llllll}
\hline & N & Minimum & Maximum & Mean & Std. Deviation \\
\hline POSTTEST & 25 & 17 & 24 & 19,84 & 1,546 \\
Valid N & 25 & & & & \\
\hline
\end{tabular}

Table 3. Data normality of test result

\begin{tabular}{llllllll}
\hline & & \multicolumn{5}{c}{ Kolmogorov-Smirnov $^{\mathrm{a}}$} & \multicolumn{2}{c}{ Shapiro-Wilk } \\
\cline { 3 - 8 } Score & Group & Statistic & df & Sig. & Statistic & df & Sig. \\
& PRETEST &, 129 & 25 &, $200^{*}$ &, 956 & 25 &, 342 \\
& POSTTEST &, 147 & 25 &, 175 &, 939 & 25 &, 141 \\
\hline
\end{tabular}

a. Lilliefors Significance Correction

*. This is a lower bound of the true significance.

In order to equip prospective teachers with an understanding of inclusive education and child protection, lecturers need to understand first the inclusion education course and the child's protection. The BPU (Main Learning Material) of Inclusive Education and Child Protection that has been developed to become a learning resource needs to be understood by lecturers in their use and material. Thus, the training of the main teaching materials of inclusive education and child protection is needed for lecturers who teach this course. Training can improve the lecturer's understanding because the training can improve the skills, knowledge and competence of a person (Palo \& Pandhi, 2003). Gupta \& Bostrom (2006) also mentioned that training is a technique to improve one's performance in a job. Based on the reasons above, this research was conducted to find out the effectiveness of the training of the main learning material (BPU) of Inclusive Education and Child Protection for lecturers at Faculty of Teacher Training and Education, Sebelas Maret University in improving the understanding of lecturers in using and understanding the main learning book of inclusive education and child protection.

\section{METHOD}

This research used experimental approaches by giving pre and post test. Intervention that given to participants is training with adulth learning approach. Training implemented in one day started with explanation, individual learning, discussion, simulation, and presentation. Learning material taken from material which is provided in main learning material (BPU) of Inclusive Education and Child Protection, arranged by Yusuf et al. (2017). The book included of 12 Chapters and incorporated several attachments related to inclusive education and child protection.

The subject of this research is twenty-five lecturers from 25 Programs at Faculty of Teacher Training and Education, Sebelas Maret University. They are Lecturers and Candidates of Lecturers for Inclusive Education Course at Faculty of Teacher Training and Education, Sebelas Maret University. They have varied educational backgrounds and not from Special Education Program. With this characteristic, it is concluded that the training participants' understanding on inclusive education, child protection, and special needs children is still very limited, but they are prepared to improve the understanding of inclusive education level in Faculty of Teacher Training and Education, Sebelas Maret University with the weight of 2 credits.

The data were collected by using a special instrument that measures the concept of comprehension test and the substance of Inclusive Education study which consists of 25 questions. The research procedure is done by three stages (1) pre test, (2) training with andragogy educational approach, and (3) post test. 
Table 4. Terms of the hypothesis testing

\begin{tabular}{|c|c|c|c|c|}
\hline Hypothesis & $\begin{array}{l}\text { Asymp. } \\
\text { (2-tailed) }\end{array}$ & Sig. & Taraf signifikansi (a) & Kesimpulan \\
\hline $\begin{array}{l}\text { Hypothesis null }\left(\mathrm{H}_{0}\right) \text { : } \\
\text { Training of the main learning material } \\
\text { (BPU) of Inclusive Education and Child } \\
\text { Protection is not effective }\end{array}$ & $>0.05$ & & 0.05 & $\begin{array}{l}\mathrm{H}_{0} \text { accepted, Ha } \\
\text { denied }\end{array}$ \\
\hline $\begin{array}{l}\text { Hipotesis alternative }\left(\mathrm{H}_{\mathrm{a}}\right) \text { : } \\
\text { Training of the main learning material } \\
(\mathrm{BPU}) \text { of Inclusive Education and Child } \\
\text { Protection is effective }\end{array}$ & $<0.05$ & & 0.05 & $\begin{array}{l}\mathrm{H}_{0} \text { denied, Ha ac- } \\
\text { cepted }\end{array}$ \\
\hline
\end{tabular}

Table 5. Paired sample t-test result

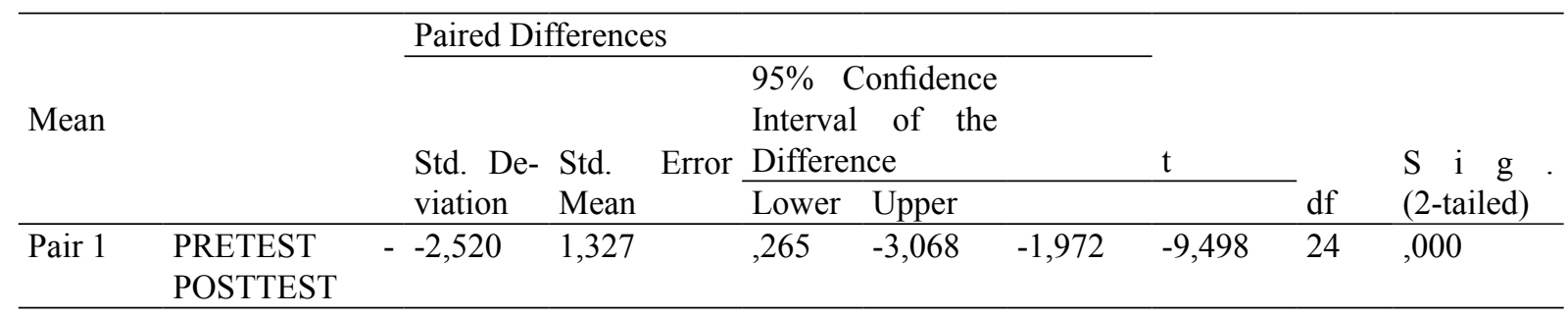

Data analysis was using descriptive statistical analysis technique continued T-test for difference test with significance level of 0.05 . If the $\mathrm{T}$-Test result is smaller than probability 0.05 then the training is declared effective and vice versa.

\section{FINDINGS AND DISCUSSION}

\section{Findings}

Based on analysis result in Table 1 and Table 2, it was conducted that pretest mean score is 17,32 and posttest mean score is 19,84 . Descriptively, it shows that posttest score is higher than pretest score. The findings indicates that trainning is effective to enhance the comprehension in understanding inclusive education course. To determine differential significances of pre and post test, Paired sample t-test and data normality test was used to determine whether there was a statistically significant difference in distance run between the two trials.

Based on the table 3, it shows that the value of $\mathrm{z}$ $\left(\mathrm{P}_{\text {value }}\right)$ pretest $=0.342$ and $\mathrm{z}\left(\mathrm{P}_{\text {value }}\right)$ posttest $=0.141$. the both has $\left.\mathrm{P}_{\text {value }}>0.05\right)$. It is concluded that data is normally distributed. Because of the data is normally distributed, then Paired sample t-test was used to determine whether there was a statistically significant difference in distance run between the two trials.

To prove the hypothesis that Training of the main learning material (BPU) of Inclusive Education and Child Protection is effective for improving the understanding of concept and subtances of Inclusive
Education course, Paired sample t-test was used to determine whether there was a statistically significant difference

Based on Paired sample t-test result above, it can be seen that the valuewith $\mathrm{P}$ (P-value $)=0.000$ $(0.000<0.05)$. It can be concluded that $\mathrm{H}_{0}$ is denied and $\mathrm{H}_{\mathrm{a}}$ is accepted. It showed that Training of the main learning material (BPU) of Inclusive Education and Child Protection is effective in improving the understanding of lecturers in using and understanding the main learning book of inclusive education and child protection

\section{Discussion}

The results of data analysis show that inclusive education training and child protection are effective in improving understanding of concept and substance of study for Lecturers in Higher Education. This is shown in the data analysis results both descriptive and statistical test.

The effectiveness of training on the use of inclusive education and child protection education materials is in line with Becker and Gehard (1996), Bowling (2007) and Davenport (2006) suggesting that training has a lot to do to make participants feel that there are a need and interest in the research related to their work. Lecturers of trainees generally have non-Special Education backgrounds so that the understanding of the concepts and substance of the Inclusive Education course is rated very less. Driven by the spirit and duty of the Study Program as a candidate for the course 
of Inclusive Education, the curiosity and the need to have sufficient knowledge in the field of special education becomes very high. This encouragement causes why post-test results far exceed pre-test results. This training proves that the lecturers have a strong motivation and commitment to improving and teach the subject of Inclusive Education. The results of this study is also supported by previous research which states that psychological training can provide motivation and commitment in a person to improve his competence in work (Cheng \& Ho, 2001; Liu, 2002; Pool \& Pool, 2007; Wang, 2001, Rowden \& Conine, 2005)

Increasing lecturers' understanding of inclusive education is an interesting finding because the lecturers will be able to prepare students to understand the concept of inclusive education appropriately which in turn the graduates have the readiness to become teachers in inclusive schools.

Understanding of the regular teachers on inclusive education today is still diverse and not as expected. Understanding wrong concepts can lead to the wrong service for children with special needs who are learning in inclusive classes. A research conducted by Sunardi (2009) found that the inclusive education is still being superficially understood, that is to include children with special needs to regular schools without any effort to accommodate their particular needs. In another study Yusuf et al. (2012) found that Principal and Teacher performance in inclusive education, still at moderate and low levels. This is due to various factors, narrow understanding, low knowledge, limited socialization, inadequate support facilities, inexperience, and weak coordination of inclusive education. The results of this study can be understood because teachers in regular schools generally have non-Special Education educational background Education and college time in Higher Education has never received the course of Inclusive Education. In the future, teachers in regular schools are expected to be better able to handle learning in the inclusive class setting because they have received inclusive education through lectures at higher education.

\section{CONCLUSION AND SUGGESTION}

\section{Conclusion}

Based on analysis result, it showed that there was differences between pre and post test mean score (17,32 and 19,84). Then the result of Paired t-test showed that there was a statistically significant difference between pre-post test mean score $(\mathrm{p}=0.000<0.05)$. It concluded that inclusive education training and child protection are effective in improving understanding of concept and substance of study for Lecturers in Higher Education.

\section{Suggestion}

Based on these results, it is recommended that Inclusive Education course could be implemented as the Basic Subject of Education (MKDK) in all universities of Education in Indonesia. It can be started by preparing Lecturers as candidates for the lecturers of Inclusive Education. The training model and teaching materials that applied in Faculty of Teacher Training and Education, Sebelas Maret University can be disseminated to others higher education.

\section{REFERENCES}

Becker, B., \& Gerhard, B. (1996). The impact of human resource management on organizational performance: Progress and prospects. Academy of Management Journal, 39, 779-801.

Bowling, N. A. (2007). Is the job satisfaction-Job performance relationship spurious? A metaanalytic examination. Journal of Vocational Behavior, 71, 167-185.

Cheng, E. W. L., \& Ho, D. C. K. (2001). The influence of job and career attitudes on learning motivation and transfer. Career Development International, $6,20-27$.

Davenport, T. H. (2006). Competing on Analytics. Harvard Business Review, 84(1), 98-107

Gupta, S., Bostrom, R.P. . (2006). End-User Training Methods: What We Know, Need to Know. ACM

Kugelmass, J. W. (2004), The Inclusive School : Sustaining Equity and Standards, Teacher College Press, Teacher College, Columbia University New York and London.

Liu, M. C. (2002). Learning satisfaction and learning performance of Taipei Elementary School (Unpublished master's thesis). National Taiwan Taipei Normal University, Taiwan.

O’Neil, J. (1995). Can Inclusion Work? A Conversation with James Kauffman and Mera Sapon-Sevin. Educational Leadership, 52(4), 7-11

Palo, S., Padhi, N.( 2003). Measuring Effectiveness of Total Quality Management Training': An Indian Study. International Journal of Training and Development, 3(7), 3-16

Pool, S., \& Pool, B. (2007). A management development model. Journal of Management Development, 26, 353-369.

Rowden, R. W., \& Conine, C. T. (2005). The impact of workplace learning on job satisfaction in small US commercial banks. Journal of Workplace Learning, 17, 216-230. doi:10.1108/13665620510597176 
Schwap, S. (2014). Evaluation Of Short Version Of The Illinois Lonelinois And Sosial Satisfaction Scale On A Sample Of Students With And Without Special Educational Needs-An Empirical Study With Primary And Secondary Students In Austria. British Journal of Special Education

Stainback, S., \& Stainback, W. (1990), Inclusion, A Guide for Educators, Paul. H. Brokes Pubisihing, Co. Baltimore, London, Toronto, Sydney.

Staub., \& Peck. (1995). What area the outcomes for Nondisabled students. Boston : Educational Leadership

Sunardi. (2009). Isuues and Problems on Implementation of Inclusive Education for Disable Children In Indonesia. Tsukuba: CRIED - University of Tsukuba
Sunaryo. (2009). Manajemen Pendidikan Inklusif (Konsep, Kebijakan, dan Implementasinya dalam Perspektif Pendidikan Luar Biasa), Jurusan PLB FIP UPI Bandung

Undang-Undang Nomor 23 tahun 2002 Tentang Perlindungan Anak

Wang, C. H. (2001). Learning behavior, learning satisfaction, and learning performance in Internet class (Unpublished master's thesis). Da-Ye University, Taiwan.

Yusuf, M., Indianto, R., \& Munzayanah. (2012). Kajian Tentang Implementasi Pendidikan Inklusif Sebagai Alternatif Penuntasan Wajib Belajar Pendidikan Dasar Bagi Anak Berkebutuhan Khusus Di Kabupaten Boyolali, Laporan Penelitian, Lembaga Penelitian dan Pengabdian Masyarakat Universitas Sebelas Maret. 